\title{
IDENTIFIKASI OBAT PENGINDUKSI KERUSAKAN HATI PADA PASIEN HEPATITIS DI RUMAH SAKIT ABDUL WAHAB SJAHRANIE
}

\author{
Tiara Dewi*, Muhammad Amir Masruhim, Riski Sulistiarini \\ Laboratorium Penelitian dan Pengembangan FARMAKA TROPIS \\ Fakultas Farmasi Universitas Mulawarman, Samarinda, Kalimantan Timur \\ *Email : tiaradewi33@gmail.com
}

\begin{abstract}
Hepatitis is one of liver disease that caused by virus. On the treatment of hepatitis still found hepatotoxic drugs that give to hepatitis patients and feared make liver damage be worsen. This study aims to determine the characteristics of patients with hepatitis, found hepatotoxic drugs that give to hepatitis patient and determine percentage of hepatotoxic drugs that used by hepatitis patient. This study is a non-experimental research design with purposive sampling and descriptive analysis. Total samples of this study is 77 patients. The results of this study indicate that the most characteristic is male patient (93.50\%) at the age of 18-40 years (59.74\%) and of 77 subjects study found 60 patients (77.92\%) get hepatotoxic drugs and the average percentage of hepatotoxic drugs that given to 60 patients is $48 \%$. Hepatotoxic drug that most widely used is paracetamol with a percentage of $9.37 \%$
\end{abstract}

Key words : Identification, hepatotoxic drug, hepatitis

\begin{abstract}
ABSTRAK
Hepatitis merupakan salah satu penyakit pada organ hati yang disebabkan oleh virus. Pada pengobatan hepatitis masih ditemukan pemberian obat-obat yang berefek hepatotoksik yang dikhawatirkan dapat memperburuk kerusakan hati. Penelitian ini bertujuan untuk mengetahui karakteristik pasien hepatitis, menemukan adanya pemberian obat-obat hepatotoksik pada pasien hepatitis dan mengetahui persentase pemberian obatobat hepatotoksik tersebut. Penelitian ini merupakan penelitian non eksperimental dengan rancangan purposive sampling dan analisis data dilakukan secara deskriptif. Jumlah sampel penelitian ini adalah 77 pasien. Hasil dari penelitian ini menunjukkan bahwa karakteristik terbanyak adalah pasien berjenis kelamin laki-laki (93,50\%) dengan usia 18-40 tahun $(59,74 \%)$ dan dari 77 subjek penelitian diketahui 60 pasien $(77,92 \%)$ mendapatkan obatobat hepatotoksik dan persentase rata-rata obat-obat hepatotoksik yang diberikan pada 60 pasien tersebut adalah $48 \%$. Obat hepatotoksik yang paling banyak digunakan adalah parasetamol dengan persentase sebesar $9,37 \%$.
\end{abstract}

Kata kunci : Identifikasi, obat hepatotoksik, hepatitis

\section{PENDAHULUAN}

Hati merupakan organ yang penting bagi tubuh manusia dan salah satu fungsinya adalah pengaturan homeostasis tubuh yang meliputi metabolisme, biotransformasi, sintesis, 
penyimpanan dan imunologi. Namun hati dapat mengalami kerusakan yang disebabkan virus, penggunaan obat dalam jangka waktu lama ataupun karena gaya hidup yang tidak sehat seperti konsumsi alkohol. Gangguan fungsi hati masih menjadi masalah kesehatan besar di negara maju maupun berkembang. Menurut Ditjen Bina Kefarmasian dan Alat Kesehatan, Indonesia merupakan negara dalam peringkat endemik tinggi mengenai penyakit hati. ${ }^{1}$

Salah satu penyakit pada organ hati yang sering ditemukan adalah hepatitis. Hepatitis merupakan penyakit berupa peradangan pada organ hati dan umumnya disebabkan oleh beberapa virus seperti HAV, HBV, HCV, HDV dan HEV. Berdasarkan hasil riset kesehatan dasar (RISKESDAS) yang dilakukan oleh Badan Penelitian dan Pengembangan Kesehatan (Balitbangkes) pada tahun 2013 diketahui bahwa di Kalimantan Timur prevalensi penyakit hepatitis A sebesar 27,1\%; hepatitis B sebesar 8,7\% dan hepatitis $\mathrm{C}$ sebesar 5,2\%. ${ }^{2}$ Sedangkan berdasarkan data yang diperoleh dari observasi yang dilakukan pada Rumah Sakit Daerah Kalimantan Timur diketahui bahwa penderita hepatitis A berjumlah 402 orang pada tahun 2013 dan meningkat menjadi 424 orang pada tahun 2014. Penderita hepatitis B berjumlah 5 orang pada tahun 2013 dan meningkat menjadi 12 orang pada tahun 2014. Sedangkan untuk hepatitis viral akut lainnya (hepatitis C, D dan E) berjumlah 3 orang.

Selain disebabkan oleh virus, penyakit peradangan pada hati juga dapat disebabkan oleh penggunaan obat-obatan dalam jangka waktu panjang atau yang disebut drug induced liver injury. Drug Induced Liver Injury (DILI) adalah istilah lain dari hepatotoksik yang diinduksi oleh obat. DILI merupakan penyebab utama kegagalan hati akut dan transplantasi dinegara-negara barat. Di Amerika Serikat, sekitar 2000 kasus gagal hati akut terjadi setiap tahun dan lebih dari 50\% disebabkan oleh obat $39 \%$ disebabkan asetaminofen, $13 \%$ reaksi idiosinkratik terhadap obat lainnya). Sekitar $75 \%$ reaksi idiosinkratis dari obat menyebabkan transplantasi hati atau kematian. ${ }^{3}$

Kerusakan fungsi hati dan komplikasi yang terjadi dapat menyebabkan terapi yang diterima pasien begitu komplek dan banyak. Saat penyakit hati berkembang, perubahan fungsi normal hati dan kerusakan hati semakin meningkat. Berdasarkan hasil penelitian diketahui pasien gangguan fungsi hati masih menggunakan obat penginduksi kerusakan hati sebesar 35,32\% dengan 28 jenis obat. Jenis terbanyak obat yang digunakan adalah ranitidine, seftriaxone, spironolactone, furosemide, dan parasetamol. Hal ini menunjukkan bahwa masih banyaknya penggunaan obat penginduksi kerusakan hati yang masih digunakan oleh pasien gangguan fungsi hati. ${ }^{4}$ Penggunaan obat penginduksi kerusakan hati seharusnya tidak diberikan pada pasien yang mengalami gangguan fungsi hati karena penyakit hati yang dialami atau adanya virus sistemik dapat meningkatkan kerentanan terjadinya kerusakan hati oleh obat. ${ }^{5}$

Berdasarkan hal tersebut di atas, peneliti tertarik untuk mengidentifikasi penggunaan obat penginduksi kerusakan hati pada pasien hepatitis di Rumah Sakit Abdul Wahab Sjahranie dimana obat-obat tersebut dapat memperparah kerusakan hatinya. Sehingga dengan adanya penelitian ini diharapkan dapat memperbaiki pelayanan kesehatan demi menunjang kesehatan pasien tersebut.

\section{METODE PENELITIAN}

Jenis penelitian ini adalah penelitian non eksperimental dengan analisa deskriptif dan pengambilan data dilakukan secara retrospektif. Pengertian studi retrospektif adalah meneliti ke belakang dengan menggunakan data sekunder untuk melihat apakah ada hubungan atau tidak antara penyakit dan faktor resiko yang terdapat pada orang yang sakit. Sumber data yang diolah dalam penelitian ini adalah data rekam medis pasien hepatitis yang melakukan rawat jalan di RSUD Abdul Wahab Sjahranie selama tahun 2014. 
Instrumen penelitian yang digunakan berupa lembar pengumpul data yang memuat nomor rekam medis pasien, umur, jenis kelamin, obat yang digunakan dan dosis obatnya. Data yang diperoleh selanjutnya dianalisa secara deskriptif meliputi karakteristik pasien, persentase pemberian obat-obat hepatotoksik dan obat-obat hepatotoksik apa saja yang masih diberikan pada pasien hepatitis di RSUD Abdul Wahab Sjahranie tersebut.

\section{HASIL DAN PEMBAHASAN}

Hasil pengolahan data menunjukkan bahwa jumlah pasien hepatitis yang melakukan rawat jalan pada tahun 2014 sebanyak 150 pasien dan pasien yang memenuhi kriteria inklusi sebanyak 77 pasien . Rekam medik pasien yang memenuhi kriteria inklusi kemudian dianalisis karakteristik dan obat-obat hepatotoksik apa saja yang diberikan pada pasien hepatitis tersebut.

1. Karakteristik Subjek Penelitian

Data hasil pengelompokan pasien hepatitis berdasarkan usia dan jenis kelamin disajikan dalam Tabel 1.

Tabel 1. Karakteristik subjek penelitian

\begin{tabular}{lcc}
\hline \multicolumn{1}{c}{ Karakteristik } & $\begin{array}{c}\text { Jumlah } \\
\mathbf{N = 7 7}\end{array}$ & Persentase (\%) \\
\cline { 1 - 1 } 1. Jenis Kelamin & 54 & $70,13 \%$ \\
\cline { 1 - 1 } a. Laki-laki & 23 & $29,87 \%$ \\
b. Perempuan & & \\
\cline { 1 - 1 } 2. Usia (tahun) & 1 & $1,29 \%$ \\
\hline a. $0-5$ & 3 & $3,90 \%$ \\
b. 5-11 & 3 & $3,90 \%$ \\
c. 12-17 & 46 & $59,74 \%$ \\
d. 18-40 & 22 & $28,57 \%$ \\
e. $41-65$ & 2 & $2,60 \%$ \\
f. $>65$ & &
\end{tabular}

Jumlah subjek penelitian yang berjenis kelamin laki-laki lebih besar dibandingkan jumlah subjek penelitian yang berjenis kelamin perempuan. Hal ini dikarenakan faktor hormon dari laki-laki dan perempuan. Laki-laki memiliki hormon androgen yang lebih banyak dibandingkan dengan perempuan dimana hormon ini dapat mengurangi kekebalan selular melalui perubahan jumlah limfosit B dan T. Sedangkan pada perempuan memiliki hormon esterogen yang dapat mempengaruhi perlindungan terhadap sel-sel hati dan proses regenerasi hepatik. Inilah yang menyebabkan laki-laki lebih rentan terinfeksi virus hepatitis dibandingkan perempuan. ${ }^{6}$

Tabel I juga menunjukkan bahwa hepatitis juga banyak diderita oleh kelompok usia 18-40 tahun atau usia dewasa. Banyak faktor yang mempengaruhi infeksi virus hepatitis pada usia dewasa. Salah satunya adalah melemahnya respon imun dikarenakan hubungan antara bertambahnya umur dengan kerusakan fungsi imun yang diperantarai oleh sel. ${ }^{7}$

2. Persentase Penggunaan Obat-Obat Hepatotoksik

Persentase jumlah subjek penelitian yang menggunakan obat berpotensi hepatotoksik dapat dilihat pada Gambar 1. 


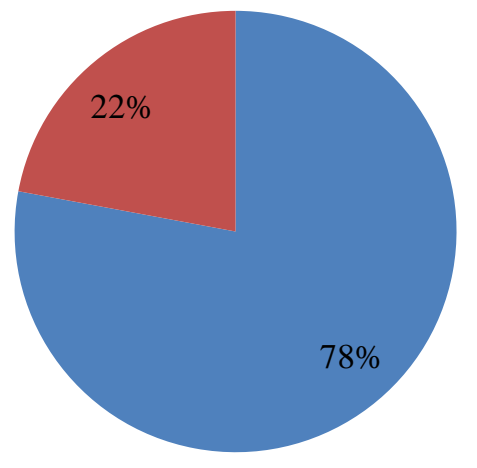

$$
\begin{aligned}
& \text { Pasien yang } \\
& \text { diberikan obat } \\
& \text { hepatotoksik } \\
& \text { Pasien yang tidak } \\
& \text { diberikan obat } \\
& \text { hepatotoksik }
\end{aligned}
$$

Gambar I. Persentase penggunaan obat hepatotoksik

Data yang diperoleh menunjukkan bahwa 60 pasien $(77,92 \%)$ dari total subjek penelitian yang menggunakan obat yang berpotensi hepatotoksik dan 17 pasien $(22,08 \%)$ dari total subjek penelitian yang tidak mendapatkan terapi obat yang berpotensi hepatotoksik. Persentase rata-rata obat hepatotoksik yang diberikan pada 60 pasien tersebut adalah sebesar $48 \%$. Obat - obat hepatotoksik sering diberikan pada pasien hepatitis umunnya bertujuan untuk menghilangkan gejala penyakit hepatitis itu sendiri seperti nyeri, demam, mual dan muntah. Selain itu, obat-obat hepatotoksik yang diberikan juga merupakan obat-obat yang digunakan sebagai terapi penyakit lain yang diderita oleh pasien. Dari data yang diperoleh diketahui bahwa terdapat 43 jenis obat-obat hepatotoksik yang diberikan pada subjek penelitian. Persentase golongan obat yang berpotensi hepatotoksik yang diberikan pada pasien hepatitis dapat dilihat pada Gambar II. Sedangkan persentase jenis obat yang berpotensi hepatotoksik yang digunakan dapat dilihat pada Gambar III.

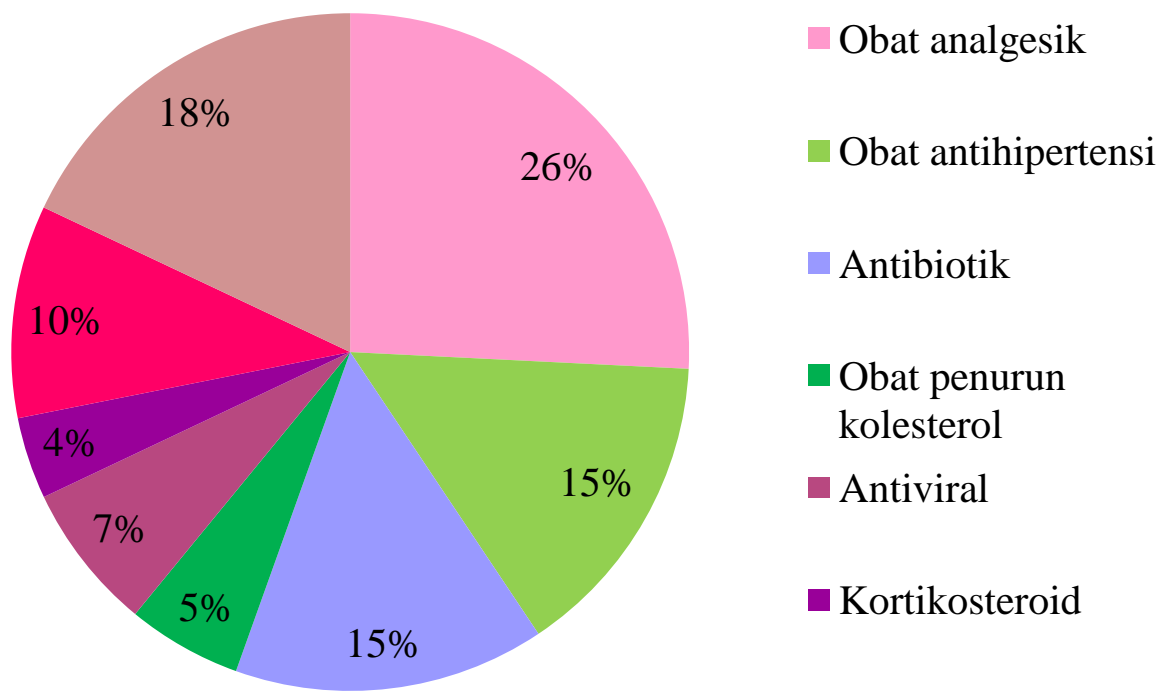

Gambar II. Persentase golongan obat berefek hepatotoksik yang digunakan pada pasien hepatitis 


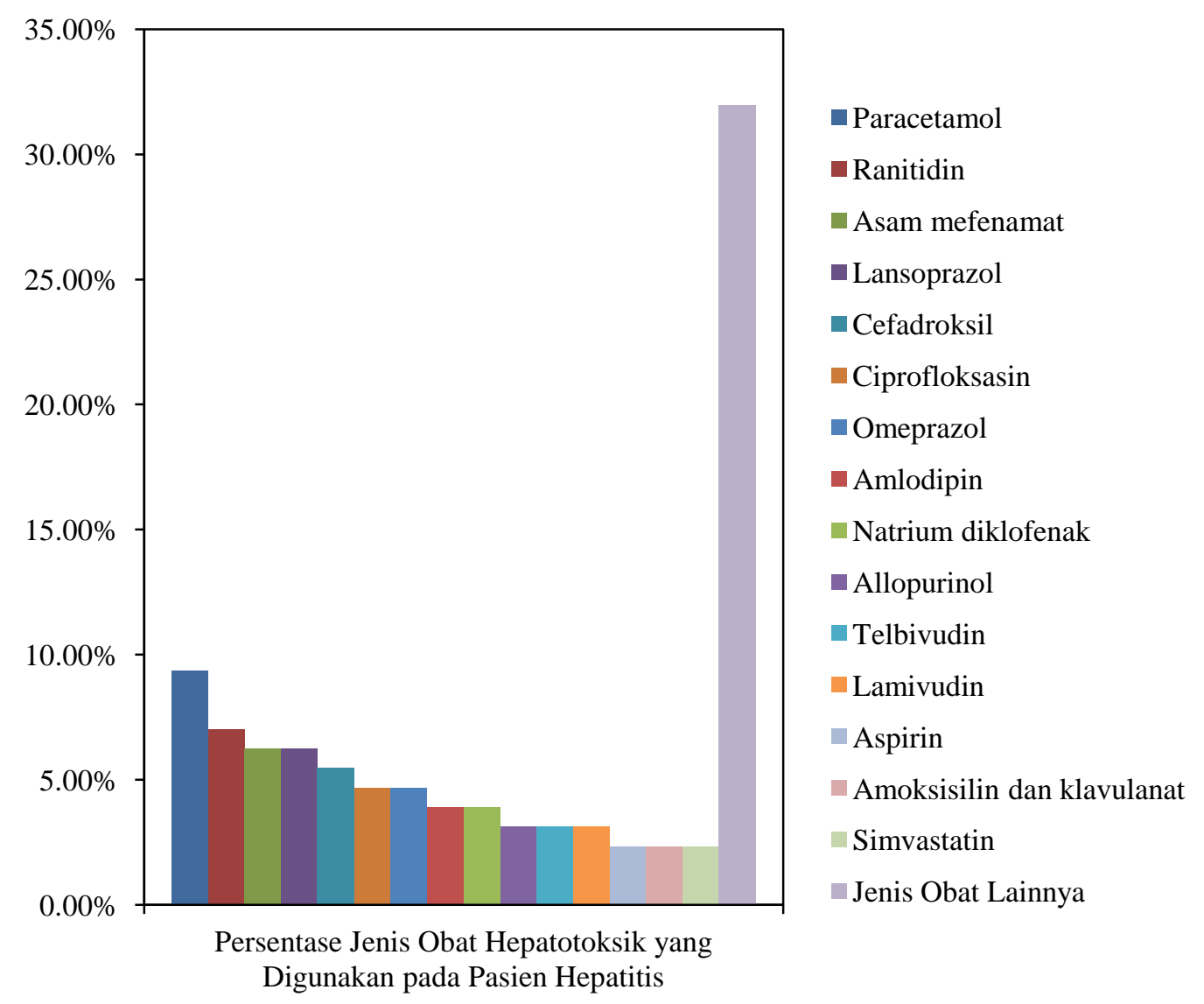

Gambar III. Persentase jenis obat hepatotoksik yang digunakan pada pasien hepatitis

Obat-obat hepatotoksik yang paling banyak digunakan adalah parasetamol (9,37\%), ranitidin $(7,03 \%)$ dan asam mefenamat $(6,25 \%)$. Acetaminophen (paracetamol) yang digunakan secara rutin dan melebihi dosis dapat menyebabkan terjadinya kerusakan hati. Parasetamol dapat menyebabkan nekrosis hepatosit sentrilobular yang dikarakterisasi dengan piknosis inti sel dan eosinofil eosinofil sitoplasma diikuti dengan luka sel hati yang melebar. Ikatan kovalen dari N-Asetil-P-benzokuinonimin, produk oksidatif dari parasetamol menjadi grup protein sulfihidril, menghasilkan peroksidasi lipid yang menyebabkan kerusakan glutation dan menyebabkan nekrosis sel hati. ${ }^{8}$ Penggunaan paracetamol pada orang dewasa tidak diperbolehkan lebih dari 4 kali dosis sehari dan penggunaannya tidak boleh lebih dari 10 hari sedangkan untuk anak-anak penggunaannya tidak boleh lebih dari 5 hari. Jangka waktu pengggunaan obat ini menjadi lebih pendek jika pasien tersebut memiliki penyakit hati yang kronik. Acetaminophen dapat menyebabkan kerusakan hati pada orng dewasa setelah penggunaan 15 gram dalam sekali minum. ${ }^{9}$

Ranitidin merupakan obat antagonis reseptor histamin $\left(\mathrm{H}_{2}\right)$ yang umumnya digunakan untuk pengobatan gastritis. Ranitidin dapat menginduksi kerusakan hati karena metabolitnya yang menyebabkan kerusakan hati oksidatif dan metabolit yang lain menyebabkan reaksi immunoalergik. Dosis ranitidin yang dapat menyebabkan kerusakan hati ini adalah sebesar $30 \mathrm{mg} / \mathrm{kg}$ atau $50 \mathrm{mg} / \mathrm{kg} .^{10}$

Asam mefenamat juga merupakan golongan NSAID yang masih diberikan pada pasien hepatitis. Mekanisme toksisitas dari golongan NSAID diperkirakan karena adanya 
difenilamin yang biasanya terdapat dalam struktur NSAID, mengurangi kandungan ATP hepatik dan menginduksi kerusakan sel hati. Penggunaan asam mefenamat yang rutin setiap hari dapat meningkatkan aktivitas ALT plasma, sebagai penanda perubahan histopatologik karena adanya inflamasi dan nekrosis pada sel-sel hati serta bertambahnya berat hati. Tetapi, dosis tunggal dari asam mefenamat tidak menyebabkan peningkatan aktivitas plasma atau berat hati, hanya berupa penurunan ringan dari fungsi sel-sel hati. Asam mefenamat ternyata masih diberikan pada terapi pasien hepatitis yang ada di Rumah Sakit Abdul Wahab Sjahranie dan diketahuin bahwa ada 7 pasien yang menerima obat ini. Dosis asam mefenamat yang dapat menyebabkan hepatotoksisitas 10-60 kali dosis terapi pada manusia dimana dosis terapi pada manusia adalah $1,5 \mathrm{mg} / \mathrm{kg}-5 \mathrm{mg} / \mathrm{kg} .{ }^{11}$

Berdasarkan penjelasan diatas, obat-obat tersebut dapat menyebabkan kerusakan hati pada pasien dengan fungsi hati yang normal. Jika digunakan pada pasien hepatitis yang telah mengalami kerusakan di hatinya dikhawatirkan dapat mengakibatkan kerusakan hati yang lebih berat. Terlebih lagi dalam pengobatan hepatitis ini ditemukan adanya kombinasi obat-obat hepatotoksik yang diberikan dalam satu regimen terapi sehingga ada lebih dari satu obat hepatotoksik yang diberikan pada satu pasien atau umumnya disebut polifarmasi. Polifarmasi ini memiliki beberapa risiko merugikan seperti meningkatnya efek samping yang sinergis dan meningkatnya interaksi obat. Risiko merugikan dari polifarnasi ini dikhawatirkan dapat menyebabkan obat-obat yang awalnya tidak hepatotoksik menjadi hepatotoksik atau bahkan lebih berbahaya ketika obat-obat yang hepatotoksik ternyata diberikan secara bersamaan.

\section{KESIMPULAN}

Persentase pasien hepatitis yang diberikan obat yang berpotensi hepatotoksik di RSUD Abdul Wahab Sjahranie sebesar 77,92\% dengan jumlah obat terbanyak adalah parasetamol yaitu sebesar 9, 37\%.

\section{ACKNOWLEDGE}

Penulis menyampaikan terimakasih kepada pihak Rumah Sakit Abdul Wahab Sjahranie Samarinda yang telah memberikan izin untuk melakukan penelitian.

\section{DAFTAR PUSTAKA}

1. Ditjen Bina Kefarmasian dan Alat Kesehatan. 2007. Pharmaceutical Care untuk Penyakit Hati. Departemen Kesehatan RI : Jakarta

2. Balitbangkes. 2013. Riset Kesehatan Dasar. Kementrian Kesehatan RI : Jakarta

3. Cinthya, Sindy E., Ivan S. Pradipta dan Rizki Abdulah. 2012. Penggunaan Obat Penginduksi Kerusakan Hati pada Pasien Rawat Inap Penyakit Hati. Jurnal Farmasi Klinik Indonesia Voluime 1 Nomor $2: 44$

4. Hikmah, Eka Nurul. 2014. Penggunaan Obat-Obatan Penginduksi Penyakit Hati terhadap Pasien Gangguan Fungsi Hati di Rumah Sakit X Surakarta Tahun 2012. Skripsi. Universitas Muhammadiyah Surakarta.

5. Tajiri K dan Shimizu Y. 2008. Practical Guidelines for Diagnosis and Early Management of Drug-Induced Liver Injury. World J Gastroenterol Vol 14 No.44: 6774-6785

6. Wojtowicz, Ewa Jagiello; Elzbieta Baran, Grazyna Krawczuk dan Violetta Szklarczyk. 2007. Testosterone, Estradiol. Progesterone and Sex Hormone Binding Globulin (SHBG) Blood Serum Levels in Men with Acute Viral Hepatitis A or B. Med Sci Monit Volume 3 Nomor 5 : 686-691

7. Carrion, Andres F. Dan Paul Martin. 2012. Viral Hepatitis in the Elderly. American Journal Gastroenterol Volume 107 Nomor 5 
8. Pandit, Aashish; Tarun Sachdeva dan Pallavi Bafna. 2012. Drug-Induced Hepatotoxicity. : A Review. Journal of Applied Pharmaceutical Science Volume 02 Nomor 05

9. PKIDs' PHR. 2013. Ibuprofen vs Acetaminophen : Which Painkiller is Better for Children with Viral Hepatitis?

10. Nidhi, Sarma; Singh Robin dan Kumar Sunil. 2012. Different Models of Hepatotoxicity and Related Liver Diseases : A Review. International Research Journal of Pharmacy Volume 3 Nomor 7 ISSN 2230-8407

11. Somchit, Sanat, Shahrin dan Zuraini. 2004. Liver Injury Induced by the Non-Steroidal Anti-Inflammatory Drug Mefenamic Acid. Singapore Med Journal Volume 45 Nomor 11 